\title{
Visita do Presidente da República ao Reembolsável da Associação dos Servidores Civis
}

\section{Senhor Presidente :}

Ao convidá-lo, em nome da Associação dos Servidores Civis do Brasil, para neste momento descerrar a bandeira que cobre $\circ$ retrato de Vossa Excelência, para sua inauguração, permita-nos fazer esta breve alocução em que, mais uma vez, digamos, de viva voz, da nossa satisfação em receber

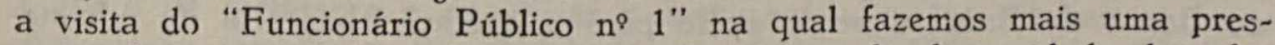
tação de contas, do mandato que nos foi outorgado de entidade de colaboração com o Estado, completando as atividades e atribuições das outras duas entidades de assistência e defesa dos servidores públicos - o I.P.A.S.E. e o D.A.S.P. - cujas diretorias aqui estão também para festejar, em conjunto com a A.S.C.B. à Vossa Excelência e a sua grande obra governamental.

Realmente Senhor Presidente, a atividade a que nos propusemos aqui, de vender o melhor e o mais barato, sem aumento e sem juros, à classe a que servimos, instalada sem nenhum auxilio governamental, nem para compra destes $2.500 \mathrm{~m} 2$ onde estamos, nem para sua armação, nem para sua estocagem e manutenção, constitue efetivamente uma tarefa ingente de colaboração com o Estado, que neste setor a executa com sacrifícios nas suas três Fôrças Armadas.

Nos setores de férias, com a Colônia de Férias de Petrópolis e a Marítima em composição; na da cultura com a Biblioteca Castro Alves, nos cursos extra-escolares e no maternal, no jardim de infância, no primário e no ginasial do nosso colégio de Botafogo; na praça de esportes, nos nossos restaurantes, na assistência jurídica, no funeral e no seguro de vida, que visa completar a previdência governamental, e sem dar outros detalhes desta obra queremos ressaltar o constante trabalho de manter o equilibrio sadio da classe defendendo-lhe as justas aspirações e conduzindo-a pelos caminhos da ordem e da disciplina.

Falta, entretanto, realizar alguns setores Senhor Presidente: A disseminação das sedes pelos Estados e aquela para qual Vossa Excelência já mandou dar o terreno, o que até agora não foi cumprido... Brasilia. Desejávamos já estar na nova Capital para recepcionar com a nossa assistência social e recreativa os colegas que lá chegassem.

Há também um setor que ainda não vencemos. Já começamos e retrocedemos - o dos gêneros alimentícios. Apesar de possuirmos neste local um armazém com três frigorificos e demais instalações para apresentarmos 
unı reembolsável de gêneros alimentícios, não conseguimos, taivez por nossa culpa, entusiasmar os órgãos próprios do govêrno a aqui se instalarem gratuitamente para esta prestação de serviços, como nos faltam recursos financeiros para nos abalançarmos diretamente a tal execução comercial.

Somos novamente muito gratos a Vossa Excelência pela compreensão dos nossos problemas, e de forma especial queremos agradecer a circular da Presidência da República que houve por bem mandar expedir a tôdas as repartições determinando abreviar as delongas no pagamento das consignações eri fôlha averbadas pelo funcionalismo a nosso favor pelas mensalidades sociais, seguro de vida, férias a crédito e compras neste Reembol sável e nos seuts dois postos filiais.

Somos gratos ainda a Vossa Excelência pela reiteração do interêsse nesse mesmo assunto, da cobrança as repartições das consignações em fôlha dado a que a Circular não operou os efeitos totais a que se destinou, indicando ao Banco do Brasil e nosso apêlo para a operação bancária de adiantamento daquelas importâncias recolhidas pelas repartições e não entregues a A.S.C.B. para satisfação dos seus compromissos sociais e comerciais.

Presidente Juscelino: Como funcionários compreendemos e colaboramos diretamente nas metas de seu programa de govêrno - Furnas, Três Marias, Induistria automobilistica e Naval, Obras contra as Sêcas, Rodoviárias e Brasília, a obra do século onde no próximo dia 28 de outubro, comemoraremos a efeméride do Servido Público - Brasília, realidade que só nos foi possível dada a sua determinação heróica e capacidade criadora.

Se não nos falhar, o engenho e arte, essa comemoração será realizada na sede que ainda iremos construir.

Mas, antes disso Senhor Presidente contamos ainda com a visita de Vossa Excelência à nossa Colônia de Férias, que costumamos chamar de nosso cartão de visita.

Senhor Presidente a bandeira da A.S.C.B. que neste instante solicito retirar, mostrará o retrato de Vossa Excelência no instante histórico para nós, em que o Presidente do Conselho Deliberativo, Ministro JoAquim Henrique Coutinho colocava o emblema de ouro da A.S.C.B. significativo da sua benemerência - retrato que neste local ficará como os outros que já estão afixados, para demonstrar a todos o nosso agradecimento e admiração.

Muito obrigado Senhor Presidente Juscelino Kubitschek de Oliveira.

Discurso proferido no Reembolsável da Associação dos Servidores Civis do Brasil pelo Presidente da República, DR. Juscelino KuBITSCHeK, em resposta ao discurso do Presidente da A.S.C.B., Dr. Ibany Ribeiro, em 17 de novembro de 1959.

A principio havia muita gente que criticava o Presidente por visitar pesscalmente tudo aquilo que representava, ou esfôrço próprio do Govêrno, ou colaboração da iniciativa particular. Mas a medida que eu ia reprodu- 
zindo, repetindo as minhas visitas e viagens, ia formando dentro dos meus olhos, da minha compreensão e de meu coração, uma imagem perfeita do esfôrço, do sacrifício e da imensa colaboração que os brasileiros vêm prestando a obra do Govêrno no sentido de acelerarmos a marcha e do engrandecimento de nossa Pátria.

Esta visita que ora faço aqui a esta grande Associação veio me revelar aspectos verdadeiramente surpreendentes para mim; já sabia, já conhecia, já havia lido, mas só co mos olhos a gente pode sentir realmente o esfôrço e a grandeza de empreendimentos como êste. Aqui estou portanto para congratular-me com os funcionários públicos do Brasil, associados a êste empreendimento, pela notável obra que aqui se realiza e especialmente $\mathrm{cnm}$ a sua eficiente e dinâmica administração. E quero neste momento declarar, que darei o mais decidido apoio a tôdas as iniciativas que acabam de ser aqui citadas, entre as quais a da construção da nova sede em Brasilia, e a outra a de facilitar e a de apoiar o movimento para se estabelecer nesta Associação também o Reembolsável para Gêneros Alimentícios. Não sei qual a providência que vou assentar, mas convidado desde logo o ilustre Presidente para comparecer ao meu Gabinete levando-me as sugestões, que porei imediatamente em execução.

Com estas rápidas palavras, nas quais eu hipoteco a minha integral solidariedade a esta instituição e à sua dinâmica administração. eu deixo aqui os votos para que Associações desta natureza se desenvolvam no Brasil, para facilitar a vida da classe do funcionalismo público, que constitui, ela própria,, a máquina do Govêrno e portanto o próprio Govêrno.

E' com a maior alegria portanto que eu agradeço esta homenagem que me acaban de prestar e hipoteco a minha integral solidariedade ao agradecimento desta instituição. 